\section{PERAN PAIKEM DALAM PROSES PEMBELAJARAN PAI}

\section{Jam'ah Abidin}

Alumni Program Pascasarjana UIN Suska Riau

\section{Abstract}

The Role of Paikem in the Islamic Education Teaching Process: In the context of formal islamic education such as in schools, there are some urgent components as determinant factors influencing the success of teaching. They are students as raw input, text books, facilities as instrumental input and physical environment as well as social-cultural environment as environmental input. The teaching process of Islamic eduaction in the classroom is less paid attention. It does not use fun and meaningful method for students. There is still old method implemented in the classromm, namely chalk and talk. Such teaching and learning process does not provide learning experience for students. Therefore, the question is how to support students to get learning experience. One of the answers is by implementing PAKEM base method. It is an abreviation of Pembelajaran Aktif, Kreatif, Efektif dan Menyenangkan (Active, Creative, and Fun Learning).

Keywords : Active Learning, Inovative, Creative and PAI.

\section{Pendahuluan}

Empat pilar pendidikan adalah sebagai landasan PAIKEM sebagaimana yang dicanangkan oleh UNISCO yaitu learning to do, learning to know, learning to be and learning to live together. Dalam proses pembelajaran, para orang tua dewasa tidak seharusnya memposisikan peserta didik sebagai pendengar ceramah guru laksana botol kosong yang diisi dengan air (sains). Peserta didik harus diberdayakan agar mau dan mampu berbuat untuk memperkaya pengalaman belajarnya (learning to do) dengan meningkatkan interaksi dengan lingkungannya, baik lingkungan fisik, sosial, maupun budaya, sehingga mampu membangun pemahaman dan pengetahuannya terhadap dunia di sekitarnya (learning to know). Diharapkan hasil interaksi dengan lingkungannya itu dapat membangun pengetahuan dan kepercayaan dirinya (learning to be). Kesempatan berinteraksi dengan berbagai individu atau kelompok yang bervariasi (learning to live together) akan membentuk kepribadiannya untuk memahami kemajemukan dan melahirkan sikap-sikap positif dan toleransi terhadap keaneragaman dan perbedaan pandangan hidup. ${ }^{1}$

Strategi pembelajaran senantiasa mengalami dinamika dalam praktek dunia pendidikan. Strategi (strategy), metode (method/tharíqah), teknik (technique/ shiyâghab), taktik (tactic/siyâsah) dan pendekatan (approach/iqtirâb), ${ }^{2}$ agak sulit menjelaskan dan membedakannya dalam pembelajaran. Strategi menunjuk pada sebuah perencanaan untuk mencapai suatu tujuan (dalam pembelajaran umpamanya), sedangkan metode adalah cara yang dapat digunakan untuk melaksanakan strategi. Strategi adalah a plan of operation achieving something, sedangkan metode adalah a way in achieving something. Strategi dalam duina pedidikan diartikan sebagai a plan method or series activities designed to achieve a particular educational goal. ${ }^{3}$

Dengan demikian, metode adalah aspek urgen dari strategi pembelajaran. Strategi pembelajaran adalah suatu rangkaian kegiatan pembelajaran yang harus dikerjakan oleh guru agar tujuan

${ }^{1}$ Hartono, Promadi, dkk, PAIKEM : Pembelajaran Aktif, Inovatif, Kreatif, Efektif dan Menyenangkan, (Pekanbaru : Zanafa Publishing, Cetakan III, Januari 2011), hlm. 21.

${ }^{2}$ Tim Prima Pena, Kamus Besar Bahasa Indonesia, edisi terbaru, (Jakarta Gitamedia, Press, t.th.), hlm. 529, 745, 216, 708 dan 732, dan Hans Wehr, $A$ Dictionary of Modern Written Arabic, Arabic-English, edited by J.Milton Cowan, (Beirut : Maktabah Lubnan, Cetaka IV, 1974), hlm. 559, 531, 755 da 441.

${ }^{3}$ Wina Sanjaya, Strategi Pembelajaran Berorientasi Standar Proses Pendidikan, (Jakarta : Kencana, Cetakan VI, Maret 2009), hlm. 124 
pembelajaran dapat dicapai secara efektif dan efisien. ${ }^{4}$ Sedangakn teknik adalah kiat yang dilakukan untuk mengimplementasikan dan mengoperasionalkan suatu metode axplanatory (eksplanatori, bersifat menjelaskan), ${ }^{5}$ umpamanya.

Metode eksplanatori dalam pembelajaran dipandang sebagai aktivitas guru untuk memotivasi, membimbing dan mengevaluasi kemampuan berfikir siswa. Bagi siswa, aktivitas menyimak eksplanatori secara cermat merupakan bagian penting dalam mengikuti proses belajar yang bersifat eksplanatori yaitu menggali informasi, mengkonfirmasikan yang telah diketahui dan merespon pada aspek yang belum diketahui. Sedangkan taktik (siasat) adalah gaya dalam melaksanakan suatu teknik pembelajaran yang sifatnya sangat individualistik dalam komunikasi eksplanatori.

Dinamika tersebut terjadi dari masa ke masa seiring dengan kebijakan pemberlakuan kurikulum pendidikan mulai kurikulum 1975, 1984, 1994, 2004, KBK (Kurikulum Berbasis Kompetensi) dan KTSP (Kurikulum Tingkat Satuan Pelajaran) 2006. Dalam catatan sejarah pendidikan nasional di tanah air, telah dikenal beberapa strategi dan pendekatan pembelajaran, seperti SAS (Sistematis, Analisis dan Sintesis), CBSA (Cara Belajar Siswa Aktif), CTL (Contextual Teaching and Learning), LSE (Life Skill Education), PBAS (Pembelajaran Berbasis Aktivitas Siswa) SPE (Strategi Pembelajaran Ekspositori), SPE (Strategi Pembelajaran Eksplanatori), SPI (Strategi Pembelajaran Inkuiri), SPBM (Strategi Pembelajaran Berbasis Masalah), SPPKB (Strategi Pembelajaran Peningkatan Kemampuan Berfikir), SPK

${ }^{4}$ Secara etiimologis efektif berarti, ada efeknya, ada pengaruhnya, ada akibatnya, sedangkan efisien adalah tepat sesuai dengan rencana, tepat dan tidak membuang-buang waktu, mampu mengerjakan kewajiban dengan baik dan tepat. Tim Prima Pena, op.cit, hlm. 240.

${ }^{5}$ To provide some explanatory remarks, artinya, memberikan keterangan yang bersifat menjelaskan, John M.Echols dan Hassan Shadily, An English-Indonesian Dictionary, (Jakarta : Gramedia Pustaka Utama, Cetakan XXV, Februari 2003), hlm. 224.
(Strategi Pembelajaran Kooperatif), SPA (Strategi Pembelajaran Afektif), ${ }^{6}$ PAKEM (Pembelajaran Aktif, Kreatif, Efektif dan Menyenangkan), PASIK (Pembelajaran Aktif, Senang, Inovatif dan Kreatif) dan paling dikenal terakhir adalah PAIKEM (Pembelajaran Aktif, Inovatif, Kreatif, Efektif dan Menyenangkan).

Sejak diberlakukannya Undang-Undang RI Nomor 2/1999 dan disempurnakan dengan Undang-Undang Nomor 20/2003 tentang Sistem Pendidikan Nasional, Undang-Undang Nomor 14 tahun 2005 tentang guru dan dosen, telah diterbitkan pula Peraturan Pemerintah Nomor 19/2005 tentang Standar Nasional Pendidikan, Peraturan Menteri Pendidikan Nasional Nomor 8 tahun 2007 tentang serifikasi guru dalam jabatan. Dalam Permendiknas tersebut diatur pelaksanaan sertifikasi guru melalui penilaian portofolio dengan 10 komponen yang bertujuan untuk mengukur 4 kompetensi pendidik yaitu kompetensi pedagogik, kepribadian, sosial dan profesional. Bagi guru yang lulus penilaian portofolio, memperoleh sertifikat pendidik dan dinyatakaan sebagai guru profesional. Sebaliknya bagi guru yang belum lulus diwajibkan mengikuti kegiatan Pendidikan dan Latihan Profesi Guru (PLPG). Dalam rambu-rambu penyelenggaraan PLPG yang berlaku secara nasional, salah satu materi wajib yang harus diberikan adalah materi PAIKEM. Oleh karena itu, sejak akhir tahun 2007, istilah PAIKEM semakin populer dalam praktek dunia pendidikan di tanah air.

\section{Pengertian PAIKEM}

Pembelajaran aktif maksudnya adalah sebuah proses giat (aktif) membangun makna dan pemahaman dari informasi, sains maupun pengalaman oleh peserta didik sendiri. Active is in the habit of doing things energertic. Artinya, terbiasa berbuat segala hal dengan menggunakan segala daya. Pembelajran yagn aktif berarti pembelajaran yagn memerlukan kegiatan semua siswa dan guru secara fisik, mental,

${ }^{6}$ Wina Sanjaya, op.cit., hlm. Viii. 
emosional, bahkan moral dan spiritual. Guru harus menciptakan suasana kondusif sedemikian rupa sehingga siswa aktif bertanya, membangun gagasan dan melakukan kegiatan yang deapagt memberikan [engalaman langsung, sehingga belajar merupakan proses aktif siswa dalam membangun pengetahuannya sendiri. ${ }^{7}$ Dalam proses belajar peserta didik tidak semestinya diperlakukan seperti bejana kosong yang pasif (jumud) yang hanya menerima kucuran ceramah sang guru tentang ilmu pengetahuan dan informasi. Oleh karena itu, dalam proses pembelajaran Agama Islam dituntut mampu menciptakan kondisi dan situasi yang kondusif peserta didik secara aktif (giat) menemukan, memproses, mengkonstruksi dan merekonstruksi ilmu pengetahuan dan keterampilan baru. ${ }^{8}$ Belajar adalah berbuat, memperoleh pengalaman tertentu sesuai dengan tujuan yang diharapkan. Oleh karena itu, pengalaman belajar siswa harus dapat memotivasi agar siswa beraktivitas melakukan sesuatu. Aktivitas tidak dimaksudkan terbatas pada aktivitas fisik, akan tetapi juga meliputi aktivitas fisikis seperti aktivitas mental. ${ }^{9}$ Umpamanya, ketika guru Agama Islam menyampaikan materi berlajar secara ceramah, sebenarnya dalam proses berceramah, guru harus memotivasi agar siswa memiliki pengalaman belajar yang bukan hanya sekadar mendengarkan, dengan tekun dan mengangguk, penjelasan guru yang pandai melawak, akan tetapi juga agar siswa memiliki pengalaman untuk menghayati materi pelajaran yang dituturkan melalui proses menyimak dan meragukan tentang segala sesuatu yang dituturkan, sehingga dari keraguan itu memunculkan keinginan siswa untuk memperdalam materi pelajaran Agama Islam khususnya. Diakui memang guru sering lupa dengan hal itu. Sebagian guru, termasuk

${ }^{7}$ Mohammad Jauhar, Implementasi PAIKEM dari Behavioristik sampai Konstruktivistik, (Jakarta: Prestasi Pustakaraya, Cetakan I, November 2011), hlm. 156.

${ }^{8}$ Ismail, Strategi Pembelajaran Agama Islam Berbasis PAIKEM, (Semarang : Media Group, Cetakan IV, 2009), hlm. 46.

${ }^{9}$ Wina Sanjaya, Perencanaan dan Desain Sistem Pembelajaran, Jakarta : Kencana, Cetakan III, 2003), hlm. 170

40 penulis sendiri, ketika berceramah berbicara membual, seperti tukang obat atau seperti pelawak yang ketika menyajikan materi penuh dengan tawa dan canda, sehingga pada akhir pelajaran siswa hampir tidak memiliki pengalaman belajar yang lebih bermakna (bernash). Kadang-kadang guru terkecoh oleh sikap siswa yang pura-pura aktif, padahal sebenarnya pasif.

Pembelajaran inovatif dimaksudkan dalam proses pembelajaran diharapkan muncul gagasan baru dan inovasi positif yang konstruktif, ${ }^{10}$ secara inspiratif dan challenging (menantang). Proses pembelajaran adalah proses yang inspiratif dan komunikatif yang memungkinkan siswa untuk mencoba dan melakukan sesuatu. Berbagai informasi dan komunikasi pemecahan masalah dalam pembelajaran bukanlah harga mati, yang bersifat mutlak (absolut), akan tetapi merupakan hipotesis yang merangsang siswa untuk berpengalaman mencoba dan mengujinya. Oleh karena itu, guru mest membuka berbagai kemungkinan yang dapat dikerjakan siswa. Guru harus menumbuhkembangkan siswa berbuat dan berfikir sesuai dengan inspirasinya sendiri, sebab pengetahuan pada dasarnya bersifat subjektif, yang mungkin dimaknai oleh setiap subjek belajar. Di samping itu, proses pembelajaran adalah proses perubahan dan menantang (changing and challenging) siswa untuk mengembangkan kemampuan berfikir inovatif yaitu merangsang kerja otak secara maksimal. Kemampuan tersebut dapat ditumbuhkan dengan cara mengembangkan rasa ingin tahu siswa melalui kegiatan mencobacoba, berfikir secara intuitif dan bereksplorasi. Apa pun yang diberikan dan dilakukan guru harus dapat merangsang siswa untuk berfikir (learning how to learn) dan melakukan (learning how to do). Apabila guru akan memberikan informasi, hendaknya tidak memberikan informasi yang instant (siap ditelan siswa), akan tetapi informasi yang mampu menggugah dan membangkitkan siswa untuk mau mengunyahnya dan mau memikirkannya sebelum ia mengambil
${ }^{10}$ Ismail, loc.cit. 
konklusi (natijah). Untuk itu, dalam hal-hal tertentu, sebaiknya guru memberikan informasi yang meragukan (syak,k), kemudian karena keraguan itulah siswa terangsang dan tergugah untuk mencari tahu dan membuktikan keabsahannya.

Pembelajaran kreatif adalah guru mampu menciptakan kegiatan belajar yang beragam sehingga memenuhi berbagai tingkat kemampuan siswa. ${ }^{11}$ Oleh karena itu, pembelajaran kreatif merupakan sebuah proses mengembangkan kreativitas peserta didik, karena pada dasarnya setiap individu memiliki imajinasi dan rasa ingin tahu yang tidak pernah berhenti. Oleh karena itu, guru dituntut mampu menciptakan aktivitas pembelajaran yang beragam sehingga seluruh potensi imajinasi peserta didik dapat berkembang secara maksimal dan optimal.

Kreativitas dapat dikembangkan dengan memberi kepercayaan, komunikasi yang bebas, pengarahan diri dan pengawasan yang tidak terlalu ketat. Dengan demikian, peserta didik akan lebih kreatif, jika :

a. Dikembangkannya rasa percaya diri pada peserta didik dan mengurangi rasa takut.

b. Memberi kesempatan kepada seluruh peserta didik untuk berkomunikasi ilmiah secara bebas dan terarah.

c. Melibatkan peserta didik dalam menentukan tujuan belajar dan evaluasinya.

d. Memberikan pengawasan yang tidak terlalu ketat dan tidak otoriter.

e. Melibatkan mereka secara aktif dan kreatif dalam proses pembelajaran secara totalitas. ${ }^{12}$

${ }^{11}$ Dasim Budimansyah, Suparlan dan Danny Meirawan, PAKEM Pembelajaran Aktif, Kreatif, Efektif dan Menyenangkan, (Bandung: Genesindo, Cetakan V, Desember 2010), hlm. 70.

${ }^{12}$ E.Mulyana, Kurikulum Berbasis Kompetensi, Konsep, Karakteristik dan Implementasi, (Bandung : Remaja Rosdakarya, 2003), hlm. 106.
Untuk mengembangkan kreativitas anak didik, perlu disimak halhal berikut :

a. Menilai dan menghargai berfikir kreatif.

b. Membantu anak menjadi lebih peka terhadap rangsangan dari lingkungan.

c. Memberanikan anak untuk memanipulasi objek (benda) dan ide.

d. Mengajar bagaimana menguji setiap gagasan secara sistematis.

e. Mengembangkan rasa toleransi terhadap gagasan baru.

f. Berhati-hati dalam memaksakan suatu pola atau contoh tertentu.

g. Mengembangkan suatu iklim kelas yang kreatif.

h. Mengajar anak untuk menilai berfikir kreatif.

i. Mengajar keterampilan anak untuk menghindari atau menguasai sanksi-sanksi teman sebaya tanpa mengorbankan kreativitas mereka.

j. Memberikan informasi tentang proses kereativitas.

k. Menghalau perasaan kagum terhadap karya-karya besar.

1. Memberanikan diri dan menilai kegiatan belajar berdasarkan inisiatif sendiri.

$\mathrm{m}$. Menciptakan duri dalam daging (thorns in the flesh) yaitu membuat anak-anak menyadari adanya masalah dan kekurangan.

n. Menciptakan kondisi yang diperlukan untuk berfikir kreatif.

o. Menyediakan waktu untuk suatu keaktifan dan ketenangan.

p. Menyediakan sumber untuk menyusun gagasan-gagasan.

q. Mendorong kebiasaan untuk menyusun implikasi ide-ide.

r. Mengembangkan keterampilan untuk memberikan kritik membangun.

s. Mendorong kemahiran pengetahuan berbagai lapangan.

t. Menjadi guru yang hangat dan bersemangat. ${ }^{13}$ 
u. Mempunyai gagasan yang orisinal.

v. Kritis terhadap pendapat orang lain.

w. Memiliki kesadaran etik-moral dan estetik yang tinggi. ${ }^{14}$

Pembelajaran efektif adalah model pembelajaran apapun yang dipilih harus menjamin bahwa tujuan pembelajran akan tercapai secara maksimal. Hal ini dapat dibuktikan dengan adanya pencapaian kompetensi baru oleh peserta didik setelah proses belajar mengajar berlangsung. Di akhir kegiatan proses pembelajaran harus ada perubahan pengetahuan, sikap dan keterampilan pada diri peserta didik. Mengajar harus dipandang sebagai upaya mengembangkan seluruh pribadi siswa. Mengajar bukan hanya mengembangkan kemampuan kognitif saja, akan tetapi juga meliputi pengembangan aspek afektif dan psikomotorik (taksonomi Bloom). Oleh karena itu, merancang pengalaman belajar siswa harus dapat mengembangkan seluruh aspek kepribadian siswa secara terintegrasi. Penggunaan metode diskusi, umpamanya, guru harus dapat merancang pengalaman belajar yang tidak hanya terbatas pada pengembangan aspek intelektual saja, akan tetapi harus mendorong siswa agar mereka dapat berkembang secara totalitas dan komprehensif, misalnya, memotivasi agar siswa dapat menghargai pendapat orang lain walaupun berbeda, memotivasi siswa agar berani mengeluarkan gagasan yang orisinal, mendorong siswa untuk bersikap transparan, jujur dan tenggang rasa.

Dalam Undang-Undang Sistem Pendidikan Nasional Nomor 20/2003 Pasal 6 dijelaskan bahwa Pendidikan Nasional berfungsi mengembangkan kemampuan dan membentuk watak serta peradaban bangsa yagn bermartabat dalam mrangka menerdaskan kehidupan bangsa, bertujuan untuk berkembangnya potensi peserta didik agar menjadi manusia yang beriman dan bertakwa kepada Tuhan Yang

${ }^{14}$ Iif Khoiru Ahmadi dan SofanAmri, PAIKEM GEMBROT, Mengembnangkan Pembelajaran Aktif, Inovatif, Kreatif, Efektif, menyenangkan, Gembira dan Berbobot, (Jakarta: Prestasi Pustakaraya, Cetakan II, April 2012), hlm. 4.

44
Maha Esa, berakhlak mulia, sehat, berilmu, cakap, kreatif, mandiri serta menjadi warga negara yang demokratis dan bertanggung jawab. ${ }^{15}$

Rumusan tujuan pendidikan di atas, sarat dengan pembentukan sikap dan nilai. Ada orang yang beranggapan bahwa sikap bukan untuk diajarkan seperti halnya matematika, fisika, sosiologi, antropologi, dllnya, akan tetapi untuk dibentuk. Oleh karena itu, yang lebih tepat untuk bidang afektif bukanlah istilah pengajaran, namun pendidikan. Oleh karena, strategi pembelajaran sikap dan nilai diarahkan untuk mencapai tujuan pendidikan yang bukan hanya dimensi kognitif, tetapi juga dimensi afektif (sikap) dan psikomotor (behavioral), melalui proses pembelajaran yang menekankan kepada aktivitas siswa sebagai subjek belajar. Afektif memang berbeda dengan pembelajaran kognitif dan psikomotor. Afektif berhubungan dengan nilai (values) yang sulit diukur, karena menyangkut kesadaran seseorang yang tumbuh secara internal. Dalam batas tertentu memang afeksi dapat muncul dalam kejadian behavioral, akan tetapi penilaiannya untuk sampai pada konklusi yang dapat dipertanggungjawabkan membutuhkan ketelitian, kecermatan dan observasi yang kontinuitas dan hal ini tidaklah mudah dilakukan, apalagi menilai perubahan sikap sebagai akibat dari proses pembelajaran yang dilakukan guru di sekolah. Kita sulit menyimpulkan bahwa sikap anak itu baik, misalnya, dilihat dari kebiasaan berbahasa yang sopan santun, ramah dan lembut, sebagai akibat dari proses pembelajaran yang dilakukan guru. Mungkin sikap itu terbentuk oleh kebiasaan dalam lingkungan keluarga, lingkungan sekitar dan pergaulan.

Pendidikan sikap (afektif) pada dasarnya adalah pendidikan nilai. Sikap merupakan refleksi dari nilai yang dimiliki. Sikap senang atau benci, simpati atau antipati seseorang terhadap objek yang dihadapinya, akan sangat dipengaruhi oleh tingkat pemahamannya (aspek kognitif) terhadap objek tersebut. Oleh karena itu, tingkat penalaran (kognitif) terhadap sesuatu objek dan kemampuan untuk

\footnotetext{
${ }^{15}$ Hartono, Promadi, dkk., op.cit., hlm. 76
} 
bertindak terhadapnya (psikomotorik) turut menentukan sikap seseorang terhadap objek yang bersangkutan, misalnya, seseorang dapat memberikan eksplanasi (penjelasan) dari berbagai sudut bahwa mencuri itu tidak baik dan dilarang oleh norma apapun (aspek kognitif). Berdasarkan pengetahuannya itu, ia tidak suka melakukannya (aspek afektif). Akan tetapi sikap negatif terhadap perbuatan mencuri baru bisa kita lihat dari tindakan nyata bahwa walaupun ada kesempatan untuk mencuri, ia tidak akan melakukannya. Dan penilaian terhadap sikap negatif terhadap mencuri itu lebih meyakinkan bahwa perbuatan mencuri itu memang tidak pernah ia lakukan, walaupun banyak kesempatan untuk itu. ${ }^{16}$ Perubahan sikap (attitude change) seseorang sangat tergantung pada sistem nilai yang dianggapnya paling benar dan kemudian sikap itu yang akan mengendalikan perilaku orang tersebut.

Nilai bagi seseorang tidaklah statis (jumud), akan tetapi dinamis. Setiap orang akan menganggap sesuatu baik (opinion change) sesuai dengan pandangannya pada saat itu. Oleh karena itu, maka sistem nilai yang dimiliki seseorang dapat dibina dan diarahkan sedemikian rupa. Apabila seseorang menganggap nilai agama adalah di atas segalanya, maka nilai-nilai yang lain akan bergantung pada nilai agama itu. Dengan demikian, sikap seseorang sangat tergantung pada sistem nilai yang dianggapnya paling benar (attitude change) dan kemudian sikap itu yang akan mengendalikan perilaku orang tersebut dalam tindakannya (behavioral change), sehingga menyebabkan ia patuh. Ada empat faktor yang merupakan dasar kepatuhan seseorang terhadap nilai tertentu yaitu :

a. Normativist, biasanya kepatuhan pada norma-norma hukum. Kepatuhan ini terdapat dalam tiga bentuk yaitu (1). Kepatuhan kepada nilai atau norma itu sendiri, (2). Kepatuhan kepada proses tanpa memedulikan kepada normanya, (3). Kepatuhan kepada hasilnya atau tujuan yang diharapkan dari peraturan itu.

16Wina Sanjaya, op.cit., hlm. 273. b. Integralist yaitu kepatuhan yang didasarkan kepada kesadaran dengan pertimbangan-pertimbangan yagn rasional.

c. Fenomenalist yaitu kepatuhan berdasarkan suara hati atau sekadar basa basi.

d. Hedonist yaitu kepatuhan berdasarkan kepentingan diri sendiri (hawa nafsu). ${ }^{17}$

Dari keempat faktor yang menjadi dasar kepatuhan setiap individual (siswa) tentu saja yang diharapkan adalah kepatuhan yang bersifat normativist, karena kepatuhan semacam itu adalah kepatuhan yang didasari atas kesadaran penuh akan makna dan fungsi nilai bagi dirinya, tanpa memedulikan apakah perilaku itu menguntungkan untuk dirinya atau tidak.

Pembelajaran menyenangkan dimaksudkan bahwa proses pembelajaran harus berlangsung dalam suasana yang menyenangkan (enjoyment), nikmat, releks (relextion) dan berkesan (impression). Suasana pembelajaran yang menyenangkan, nikmat, releks dan berkesan akan menarik minat dan antusiasme peserta didik untuk terlibat secara aktif, sehingga tujuan pembelajaran akan dapat tercapai secara maksimal. Pembelajaran yagn menyenangkan, nikmat dan berkesan akan melahirkan reward (hadiah) bagi peserta didik yang pada gilirannya akan memotivasinya semakin aktif, kreatif, efektif, inovatif dan berprestasi serta berprestise pada aktivitas belajarnya. Pada akhirnya, proses pembelajaran adalah proses yang dapat mengembangkan seluruh potensi siswa. Seluruh potensi itu hanya mungkin dapat berkembang pesat manakala siswa terbebas dari rasa stress, depresi dan emosi yang labil. Oleh karena itu, perlu diupayakan agar pengalaman belajar merupakan proses yang menyenangkan (enjoyfull learning). Proses pembelajaran yang menyenangkan dapat dilakukan antara lain yang terpenting melalui dua cara. Pertama, dengan menata ruangan yang apik dan asyik yaitu yang memenuhi unsur standar kesehatan, misalnya, dengan pengaturan cahaya yang 
terang dan ventilasi serta memenuhi unsur estetika, umpamanya, cat tembok yang segar dan bersih, bebas dari debu, lukisan dan karyakarya siswa yang tertata dengan rapi dan letak pot bunga yang cocok Kedua, melalui pengelolaan pembelajaran yang hidup dan bervariasi yaitu dengan menggunakan pola dan model pembelajaran, media dan sumber belajar yang relevan serta gaya guru yang mampu membangkitkan spirit belajar siswa yang kuat dan menggugah.

Dari uraian di atas dapat dikemukakan agaknya karakteristik Pembelajaran yang Aktif, Inovatif, Kreatif, Efektif dan Menyenangkan yaitu :

a. Adanya sumber belajar yang beragam dan tidak menghandalkan buku sebagai satu-satunya nara sumber belajar. Hal ini dilakukan dengan tujuan untuk lebih memperkaya pengalaman belajar peserta didik. Bukan untuk menafikan sama sekali buku pelajaran (buku daras/text books) sebagai salah satu nara sumber belajar peserta didik. Sumber belajar yang beraneka ragam tersebut kemudian didesain sedemikian rupa sehingga menjadi skenario pembelajaran dengan berbagai kegiatan.

b. Kegiatan belajar mengajar bervariasi secara aktif yang biasanya didominasi oleh kegiatan individual dalam beberapa menit, kegiatan berpasangan dan kegiatan kelompok kecil antara 4 sampai 5 orang untuk mengerjakan tugas-tugas yang telah disepakati bersama dan salah seorang di antaranya mempresentasikan hasil kegiatan mereka di depan kelas. Hasil kegiatan siswa itulah yang kemudian dipajang.

c. Hasil kegiatan belajar mengajar kemudian dipajang di tembok kelas, papan tulis dan bahkan ditambah dengan tali rampia di sana sini. Pajangan tersebut merupakan hasil diskusi dan komunikasi karya siswa. Pajangan hasil karya siswa menjadi satu ciri fisikal yang dapat diamati dalam proses pembelajaran.

d. Dalam mengerjakan pelbagai tugas tersebut, para siswa, baik secara individual maupun secara kelompok, mencoba mengembangkan secara maksimal mungkin kreativitasnya. Dalam melaksanakan kegiatannya yang beraneka ragam itu, tampaklah antusiasme dan rasa senang siswa.

e. Pada akhir proses pembelajaran, semua siswa melakukan aktivitas dengan refleksi yaitu mempresentasikan secara tertulis kesan dan pesan mereka terhadap proses pembelajaran yang baru saja diikutinya.

Relevansi implementasi PAIKEM minimal dapat ditelaah dari tiga aspek yaitu aspek yuridis formal, psikologis pedagogis dan berdasarkan aplikasi di lapangan bagi guru. Dalam konteks implementasi praktisnya, PAIKEM bersifat fleksibel untuk diimplementasikan dalam proses pembelajaran dalam semua jenjang pendidikan, mulai dari pendidikan anak usia dini sampai perguruan tinggi. Justru itu, PAIKEM dapat diadaptasi dan dimodifikasi untuk semua mata pelajaran, baik mata pelajaran umum maupun mata pelajaran Agama Islam.

Mental inklusif, inovatif dan kreatif dalam memilih dan memilah metode pembelajaran ini sejalan dengan semangat reformasi pendidikan yang bergulir. Semangat reformasi menghendaki adanya perubahan-perubahan mendasar dalam sistem pembelajaran. Di antaranya, bagaimana pembelajaran itu menguntungkan semua pihak, baik sekolah, guru dan terutama peserta didik. Untuk menyambut dan merealisasikan semangat itulah kiranya paradigma PAIKEM (Pembelajaran Aktif, Inovatif, Kreatif, Efektif dan Menyenangkan) sebagai sebuah strategi dan model pembelajaran dapat dijadikan sebagai salah satu alternatif khususnya dalam Pembelajaran Agama Islam.

\section{PAIKEM Dalam Tinjauan Yuridis Formal}

Dasar hukum yang melandasi diaplikasikannya PAIKEM merupakan tinjauan yuridis formal. Segala bentuk regulasi, peraturan dan kebijakan pendidikan yang berlaku di Negara Kesatuan Republik Indonesia yang di dalamnya mengatur dan memberi rambu-rambu 
tentang implementasi proses pendidikan yang berbasis PAIKEM. Berbagai bentuk regulasi dan kebijakan pendidikan dimaksud, antara lain, meliputi :

1. Undang-Undang RI Nomor 2/1989 dan Nomor 20/2003 tentang Sistem Pendidikan Nasional. Beberapa pasal terkait antara lain terdapat pada pasal 1 ayat 1 (UU No.20/2003) :

Pendidikan adalah usaha sadar dan terencana untuk mewujudkan suasana belajar dan proses pembelajaran agar peserta didik secara aktif mengembangkan potensi dirinya untuk memiliki kekuatan spiritual keagamaan, pengendalian diri, keperibadian, kecerdasan, akhlak mulia serta keterampilan yagn diperlukan dirinya, masyarakat, bangsa dan negara. ${ }^{18}$

Pasal 39 ayat 2 menjelaskan bahwa Pendidik merupakan tenaga profesional yang bertugas tenaga profesional yang bertugas merencanakan dan melaksanakan proses pembelajaran, menilai hasil pembelajaran, melakukan pembimbingan dan pelatihan serta melakukan penelitian dan pengabdian keapda masyarakat, terutama bagi pendidik pada perguruan tinggi. ${ }^{19}$

Pasal 40 ayat 2 menjelaskan bahwa Pendidik dan tenaga kependidikan berkewajiban : [a] Menciptakan suasana pendidikan yang bermakna, menyenangkan, kreatif, dinamis dan dialogis; [b] Mempunyai komitmen secara profesional untuk meningkatkan mutu pendidikan; [c] Memberi teladan dan menjaga nama baik lembaga, profesi dan kedudukan sesuai dengan kepercayaan yang diberikan kepadanya. ${ }^{20}$

${ }^{18}$ Direktorat Jenderal Pendidikan Islam, Kumpulan Undang-Undang dan Peraturan Pemerintah tentang Pendidikan, (Jakarta : Dirjen Pendis Depag RI, 2007), hlm. 15.

$$
{ }^{19} \text { Ibid., hlm. } 25 .
$$

${ }^{20} \mathrm{Ibid}$., hlm. 26.
Pasal 4 ayat 3 dan 4 menjelaskan bahwa Pendidikan diselenggarakan sebagai suatu proses pembudayaan dan pemberdayaan peserta didik yang berlangsung sepanjang hayat. Pendidikan di selenggarakan dengan memberi keteladan, membangun kemauan dan mengembangkan kreativitas peserta didik dalam proses pembelajaran. ${ }^{21}$

2. Peraturan Pemerintah Nomor 19/2005 tentang Standar Nasional Pendidikan. Dalam pasal 19 ayat 1 dijelaskan bahwa :

Proses pembelajaran pada satuan pendidikan diselenggarakan secara interaktif, inspiratif, menyenangkan, menantang, memotivasi peserta didik untuk berpartisipasi aktif serta memberikan ruang yang cukup bagi prakarsa, kreativitas dan kemandirian sesuai dengan bakat, minat dan perkembangan fisik serta psikologis peserta didik. ${ }^{22}$

Pasal 28 ayat 1 menjelaskan bahwa Pendidik harus memiliki kualifikasi akademik dan kompetensi sebagai agen pembelajaran, sehat jasmani dan rohani serta memiliki kemampuan untuk mewujudkan tujuan pendidikan nasional. ${ }^{23}$

Selanjutnya dipertegas dalam Penjelasan atas PP No. 19/2005, pasal 28 ayat 1, 2 dan 3 dijelaskan bahwa Pendidik harus memiliki kualifikasi akademik dan kompetensi sebagai pendidik sebagai agen pembelajaran (learning agent) pada ketentuan ini adalah peran pendidik antara lain sebagai fasilitator, motivator, pemacu dan pemberi inspirasi belajar bagi peserta didik (pasal 28 ayat 1). Kualifikasi akademik sebagaimana dimaksud pada ayat (1) adalah tingkat pendidikan minimal yang harus dipenuhi oleh seorang pendidik yang dibuktikan dengan ijazah dan atau sertifikat keahlian yang relevan sesuai ketentuan perundang-undangan yang berlaku (pasal 28 ayat 2). Kompetensi sebagai agen pembelajaran pada jenjang pendidikan dasar

${ }^{21}$ Ibid., hlm. 9.

22Ibid., hlm. 151

23Ibid., hlm. 154. 
dan menengah serta anak usia dini meliputi ; a. Kompetensi pedagogik, b. Kompetensi kepribadian, c. Kompetensi profesional dan d. Kompetensi sosial (padsal 28 ayat 3). ${ }^{24}$

3. Undang-Undang RI Nomor 14/2005 tentang Guru dan Dosen, menjelaskan dalam pasal-pasal berikut :

Pasal 1 ayat 1 menjelaskan bahwa Guru adalah pendidik profesional dengan tugas utama mendidik, mengajar, membimbing, mengarahkan, melatih, menilai dan mengevaluasi peserta didik pada pendidikan peserta didik usia dini jalur pendidikan formal, pendidikan dasar dan pendidikan menengah. ${ }^{25}$

Pasal 6 menjelaskan bahwa Kedudukan guru dan dosen sebagai tenaga profesional bertujuan untuk melaksanakan sistem pendidikan nasional dan mewujudkan tujuan pendidikan nasional yaitu berkembangnya potensi peserta didik agar menjadi manusia yang beriman dan bertakwa kepada Tuhan Yang Maha Esa, berakhlak mulia, sehat, berilmu, cakap, kreatif, mandiri serta menjadi warga negara yang demokratis dan bertanggung jawab. ${ }^{26}$

Dari berbagai regulasi pendidikan tersebut, baik dalam bentuk undang-undang maupun peraturan pemerintah, dapat difahami bahwa proses pendidikan dan pembelajaran pada satuan pendidikan manapun (dari pendidikan usia dini sampai perguruan tinggi) secara yuridis formal dituntut harus diselenggarakan secara aktif, inovatif, kreatif, dialogis, demokratis dan dalam suasana yang mengesankan dan bermakna bagi peserta didik. Perundangan dan peraturan pendidikan yang diterapkan di tanah air tercinta, mengindikasikan urgennya diterapkan strategi pembelajaran yang memberdayakan peserta didik.

Dalam konteks ini, PAIKEM sebagai salah satu model pembelajaran yang telah dikembangkan dan gencar dipromosikan

${ }^{24}$ Ibid., hlm. 155.

25Ibid., hlm. 73.

${ }^{26}$ Ibid., hlm. 76. implementasinya dalam praktek dunia pendidikan di Indonesia, memiliki relevansi yang kuat terhadap tuntutan yuridis formal ini.

Dalam Undang-Undang Sistem Pendidikan Nasional Nomor 20/2003 Pasal 6 dijelaskan bahwa Pendidikan Nasional berfungsi mengembangkan kemampuan dan membentuk watak serta peradaban bangsa yagn bermartabat dalam mrangka menerdaskan kehidupan bangsa, bertujuan untuk berkembangnya potensi peserta didik agar menjadi manusia yang beriman dan bertakwa kepada Tuhan Yang Maha Esa, berakhlak mulia, sehat, berilmu, cakap, kreatif, mandiri serta menjadi warga negara yang demokratis dan bertanggung jawab. ${ }^{27}$

Rumusan tujuan pendidikan di atas, sarat dengan pembentukan sikap (afektif) dan nilai (values). Ada orang yang beranggapan bahwa sikap bukan untuk diajarkan seperti halnya matematika, fisika, sosiologi, antropologi, dllnya, akan tetapi untuk dibentuk. Oleh karena itu, yang lebih tepat untuk bidang afektif bukanlah istilah pengajaran, namun pendidikan. Oleh karena, strategi pembelajaran sikap dan nilai diarahkan untuk mencapai tujuan pendidikan yang bukan hanya dimensi kognitif, tetapi juga dimensi afektif (sikap) dan psikomotor (behavioral), melalui proses pembelajaran yang menekankan kepada aktivitas siswa sebagai subjek belajar. Afektif memang berbeda dengan pembelajaran kognitif dan psikomotor. Afektif berhubungan dengan nilai (values) yang sulit diukur, karena menyangkut kesadaran seseorang yang tumbuh secara internal. Dalam batas tertentu memang afeksi dapat muncul dalam kejadian behavioral, akan tetapi penilaiannya untuk sampai pada konklusi yang dapat dipertanggungjawabkan membutuhkan ketelitian, kecermatan dan observasi yang kontinuitas dan hal ini tidaklah mudah dilakukan, apalagi menilai perubahan sikap sebagai akibat dari proses pembelajaran yang dilakukan guru di sekolah. Kita sulit menyimpulkan bahwa sikap anak itu baik, misalnya, dilihat dari kebiasaan berbahasa yang sopan santun, ramah dan lembut, sebagai akibat dari proses pembelajaran yang dilakukan guru.

${ }^{27}$ Ibid., hlm. 76. 
Mungkin sikap itu terbentuk oleh kebiasaan dalam lingkungan keluarga, lingkungan sekitar dan pergaulan.

Pendidikan sikap (afektif) pada dasarnya adalah pendidikan nilai. Sikap merupakan refleksi dari nilai yang dimiliki. Sikap senang atau benci, simpati atau antipati seseorang terhadap objek yang dihadapinya, akan sangat dipengaruhi oleh tingkat pemahamannya (aspek kognitif) terhadap objek tersebut. Oleh karena itu, tingkat penalaran (kognitif) terhadap sesuatu objek dan kemampuan untuk bertindak terhadapnya (psikomotorik) turut menentukan sikap seseorang terhadap objek yang bersangkutan, misalnya, seseorang dapat memberikan eksplanasi (penjelasan) dari berbagai sudut bahwa mencuri itu tidak baik dan dilarang oleh norma apapun (aspek kognitif). Berdasarkan pengetahuannya itu, ia tidak suka melakukannya (aspek afektif). Akan tetapi sikap negatif terhadap perbuatan mencuri baru bisa kita lihat dari tindakan nyata bahwa walaupun ada kesempatan untuk mencuri, ia tidak akan melakukannya. Dan penilaian terhadap sikap negatif terhadap mencuri itu lebih meyakinkan bahwa perbuatan mencuri itu memang tidak pernah ia lakukan, walaupun banyak kesempatan untuk itu. ${ }^{28}$ Perubahan sikap (attitude change) seseorang sangat tergantung pada sistem nilai yang dianggapnya paling benar dan kemudian sikap itu yang akan mengendalikan perilaku orang tersebut.

Komitmen seseorang terhadap suatu nilai tertentu terjadi melalui pembentukan sikap yaitu kecenderungan seseorang tehadap suatu objek, umpamanya, jika seseorang berhadapan dengan suatu objek, ia akan menunjukan fenomena senang atau benci, simpati atau antipati. Seseorang yang berhadapan dengan pendidikan sebagai suatu objek, maka manakala ia mendengarkan dan menyaksikan dialog tentang pendidikan di televisi misalnya, ia akan menunjukkan gejala kesenangannya dengan mengikuti dialog itu secara serius sampai tuntas, dan sebaliknya seseorang yang mengindikasikan fenomena antipati terhadap isu pendidikan, ia akan tutup telinga dan memindahkan channel televisinya ke program yang diminatinya.

Nilai bagi seseorang tidaklah statis (jumud), akan tetapi dinamis. Setiap orang akan menganggap sesuatu baik sesuai dengan pandangannya pada saat itu. Oleh karena itu, maka sistem nilai yang dimiliki seseorang dapat dibina dan diarahkan sedemikian rupa. Apabila seseorang menganggap nilai agama adalah di atas segalanya, maka nilai-nilai yang lain akan bergantung pada nilai agama itu. Dengan demikian, sikap seseorang sangat tergantung pada sistem nilai yang dianggapnya paling benar dan kemudian sikap itu yang akan mengendalikan perilaku orang tersebut dalam tindakannya.

\section{PAIKEM Dalam Tinjauan Psikologi Pembelajaran}

Umumnya mazhab psikologi barat (bersifat materialistis, atheistis dan sekularistis), termasuk psikoanalisis, behaviorisme, dan humanisme, tidak mengkaji jiwa (fisikis), tetapi tingkah laku. Psikologi (barat) sekarang lebih bertumpu pada kajian tingkah laku daripada jiwa (psiko) itu sendiri. ${ }^{29}$ Namun, para filosof Yunani dahulu (Sokrates, Aristoteles dan Plato) dan filosof Islam (al-Kindi, al-Razi, al-Farabi, Ibnu Sina, al-Ghazali, Ibnu Bajah, Ibnu Thufail, Ibnu Miskawaih dan Ibnu Rusyd) mengkaji secara intensif tentang jiwa (nous atau ruh). Para filosof Yunani dan Islam menekankan aspek ruhani untuk memahami tingkah laku manusia. Oleh karena itu, psikologi harus memperhitungkan aspek keruhanian manusia untuk memahami tingkah laku manusia yang krusyial itu. Menurut filosof Islam jenjang tertinggi dalam kesadaran ditempati oleh ruh yang diikuti oleh qalb (kalbu), kemudian diikuti oleh 'aql (akal) dan yang paling rendah adalah nafs (hawa nafsu). ${ }^{30}$ Dalam kaitan proses pembelajaran di

${ }^{29}$ Hasan Langgulung, Peralihan Paradigma dalam Pendidikan Islam dan Sains Sosial, (Jakarta: Gaya Media Pratama, Cetakan I, April 2002), hlm. 210.

${ }^{30}$ Ibid., hlm. 213. 
sekolah, guru perlu memahami makna psikologi menurut filosof Yunani dan Islam tersebut.

Pembelajaran atau sebelumnya dikenal dengan istilah Kegiatan Belajar Mengajar (KBM) atau disebut juga Proses Belajar Mengajar (PBM) merupakan proses interaksi antara peserta didik dengan pendidik dan sumber belajar pada suatu lingkungan belajar. Dalam aktivitas akademik rutinitas, sekolah/madrasah sebagai lembaga pendidkan bukan hanya menjadi wahana untuk berkumpul peserta didik dan guru/dosen, melainkan sarana yang berada dalam satu tatanan sistemik yang saling berkaitan. Oleh karena itu, sekolah/madrasah dipandang sebagai suatu organisasi yang membutuhkan pengelolaan secara efektif dan efisien. ${ }^{31}$

Aktivitas pembelajaran adalah fokus kegiatan akademik di sekolah/madrasah. Kualitas lulusan merupakan indikator urgen bagi keberhasilan sebuah sekolah/madrasah. Dengan demikian, guru memiliki peran dan tanggung jawab yang besar di dalam menentukan kualitas keberhasilan tersebut. Pembahasan tentang proses pembelajaran banyak merujuk kepada toeri-teori belajar, seperti classical conditioning, operant conditioning, stimulus response, behaviorism, reinforcement dan reward punishment, yang disajikan oleh para pakar pendidikan seperti Thorndike, Watson dan Skinner. ${ }^{32}$

Proses pembelajaran tradisional menitikberatkan pada metode imposisi yaitu pembelajaran dengan cara menuangkan hal-hal yang dianggap penting oleh pengajar bagi peserta didiknya. Cara ini tidak mempertimbangkan kesesuaian antara materi dengan kebutuhan, minat dan tingkat perkembangan serta pemahaman peserta didik. Paradigma psikologi kepribadian dan tingkah laku manusia serta perkembangan di bidang ilmu pendidikan pada gilirannya mampu mengubah pandangan tersebut. Faktor peserta didik dianggap sesuatu

${ }^{31}$ Peraturan Pemerintah Nomor 10/2010 tentang Pengelolaan dan Penyelenggaraan Pendidikan, (Yogyakarta : Pustaka Timur, 2010), hlm. 7.

32Ismail, op.cit., hlm. 51. yang menentukan dalam pelaksanaan dan keberhasilan proses pembelajaran. Pandangan baru berpendapat bahwa tingkah laku manusia dimotivasi oleh motif-motif tertentu. Aktivitas belajar akan berhasil apabila berdasarkan motivasi pada diri peserta didik. Peserta didik mungkin dapat dipaksa untuk melakukan suatu perbuatan, tetapi ia tidak mungkin dipaksa untuk menghayati perbuatan itu sebagaimana mestinya. Guru dapat memaksakan materi pelajaran kepada murid, tetapi tidak dapat memaksanaya untuk belajar dalam arti yang sebenarnya. Berarti tugas guru cukup berat yaitu berupaya agar peserta didik mau belajar dan memiliki keinginan belajar secara kontinuitas tanpa dibatasi waktu (long life eduction/al-tarbiyyah muddata bayât).

Sistem pembelajaran yang baik seharusnya dapat membantu siswa mengembangkan diri secara optimal serta mampu mencapai tujuan belajar. Meskipun proses belajar mengajar tidak dapat sepenuhnya berpusat pada siswa (pupil centred instruciton) seperti pada sistem pendidikan terbuka, tetapi perlu diingat bahwa pada hakekatnya siswalah yang harus belajar keras. Oleh karena itu, proses belajar mengjar perlu berorientasi pada kebutuhan dan kemampuan siswa, umpamanya, melalui pendekatan inquiry dicovery learning. Kegiatan yang dilaksanakn harus dapat memberikan pengalaman belajar yang menyenangkan dan berguna baginya. Guru perlu menyuguhkan beragam situasi belajar yang memadai untuk materi yang disajikan dan menyesuaikannya dengan kemampuan dan karakteristik serta gaya belajar siswa. Dengan demikian, guru dituntut harus kaya metodologi mengajar sekaligus terampil menerapkannya. Tidak monoton dan variatif dalam melaksanakan pembelajaran. Dalam konteks demikian, diharapkan guru dapat memperkaya dalam hal strategi, metode, teknik dan gaya mengajar sebagai estetis. Sehingga secara psikologis pedagogis, PAIKEM secara nyata memiliki relevansi dalam rangka mewujudkan proses belajar pembelajaran Agama Islam yang mampu memberdayakan peserta didik secara maksimal.

Sebagai ujung tombak bangunan peradaban ummat manusia, pendidikan sekolah berhadapan dengan kebutuhan-kebutuhan 
pembangunan manusia dalam berbagai aspeknya. Pembangunan kualitas sumber daya manusia banyak bertumpu pada kualitas guru yang mengambil perannya dalam pendidikan sekolah. ${ }^{33}$ Eksistensi pengembangannya sangat tergantung pada dunia pendidikan. ${ }^{34}$ Kualitas pendidikan di sekolah adalah tanggung jawab bersama pihak sekolah, orang tua dan masyarakat. Masyarakat sebagai pengguna produk kependidikan sekolah turut berpartisipasi dalam membina dan memperlancar proses kependidikan di sekolah agar efektif. ${ }^{35}$ Penguasaan terhadap berbagai strategi pembelajaran merupakan hal yang mesti bagi seorang guru. Guru bukan hanya bertindak sebagai pengajar, tetapi sebagai motivator dan fasilitator dalam proses belajar. ${ }^{36}$ Kritik terhadap rendahnya kualitas pendidikan di tanah air, boleh jadi salah satu faktornya adalah disebabkan oleh kurang aktif dan kreatifnya anak didik dan tenaga pendidik yang diserahi melaksanakan aktivitas pendidikan dan pendidik yang dianggap kurang memiliki profesionalitas tentang strategi pembelajaran berbasis PAIKEM.

Salah satu masalah yang dihadapi dunia pendidikan kita adalah masalah lemahnya proses pembelajaran. Dalam proses pembelajaran, anak (didik) kurang dimotivasi untuk mengembangkan kemampuan berfikir (mereka). Proses pembelajaran di dalam kelas tampaknya diarahkan kepada kemampuan anak untuk menghafal informasi (materi pelajaran), otak anak dipaksa untuk mengingat berbagai informasi tanpa dituntut untuk memahami informasi yang diingatnya

${ }^{33}$ Muhmidayeli, Filsafat Pendidikan, (Bandung: Refika Aditama, Cetakan Kesatu, Maret 2011), hlm. 37.

${ }^{34}$ Muhmidayeli, Teori-Teori Pengembangan Sumber Daya Manusia, (Pekanbaru: PPs UIN suSka Riau dan LSFK2P, Cetakan Kesatu, Oktober 2007), hlm. v.

${ }^{35}$ Muhmidayeli, et.al, Membangun Paradigma Pendidikan Islam, (Pekanbaru: PPs UIN Suska Riau, Cetakan I, Juni 2007), hlm. 73.

${ }^{36}$ Hasan Langgulung, Pendidikan Islam dalam Abad ke 21, (Jakarta: Pustaka Husna Baru, Cetakan III, Oktober 2003), hlm. 103. itu untuk menghubungkannya dengan kehidupan sehari-hari. ${ }^{37}$ Salah satu akibatnya, ketika anak didik tamat dari sekolah, mereka kaya secara teoritis, akan tetapi miskin implementasi. Proses pembelajaran akan efektif manakala guru mampu memanfaatkan sarana dan prasarana secara tepat. Untuk itu, perlu perencanaan yang matang bagaimana memanfaatkannya untuk keperluan pencapaian tujuan pembelajaran secara efektif dan efisien. Perencanaan pembelajaran merupakan proses yang kompleks dan tidak sederhana. Proses perencanaan memerlukan pemikiran yang matang dan terarah, sehingga akan berfungsi sebagai pedoman dalam mencapai tujuan pembelajaran.

Proses pembelajaran merupakan operasionalisasi dari Rencana Pelaksanaan Pembelajaran (RPP) atau Rencana Mengajar (lesson plan) yang telah disusun oleh guru. RPP merupakan operasionalisasi dari silabus, silabus merupakan operasionalisasi dari KTSP dan KTSP pada hakekatnya merupakan operasionalisasi dari standar isi dan standar kelulusan yang telah ditetapkan oleh Menteri Pendidikan Nasional, Permendiknas Nomor 22 dan 23/2006.38

Pembelajaran bukan hanya sekadar menyampaikan materi pelajaran, akan tetapi merupakan suatu proses pembentukan perilaku siswa. Proses pembentukan perilaku tidak dapat dilaksanakan dengan mudah dan dalam waktu yang singkat. Siswa Sekolah Menengah Pertama misalnya adalah organisme yang unik dan sedang berkembang menuju masa remaja yang banyak mengalami perubahan. Di samping itu, mereka memiliki minat dan bakat yang berbeda. Mereka juga memiliki gaya belajar yang berbeda. Itulah sebabnya proses pembelajaran adalah proses yang kompleks, yang harus memperhitungkan berbagai kemungkinan yang akan terjadi.

${ }^{37}$ Wina Sanjaya, Strategi Pembelajaran Berorientasi Standar Proses Pendidikan, (Jakarta: Kencana, Cetakan VI, 2009), hlm. xiii.

${ }^{38}$ Dasim Budimansyah, Suparlan dan Danny Meirawan, PAKEM: Pembelajaran Aktif, Kreatif, Efektif dan Menyenangkan, (Bandung: Genesindo, Cetakan V, Desember 2010), hlm. 146. 
Kemunginan-kemungkinan itulah yang selanjutnya memerlukan perencanaan yang matang dari setiap guru. ${ }^{39}$

Proses pembelajaran akan efektif manakala memanfaatkan berbagai sarana dan prasarana yang tersedia, termasuk memanfaatkan berbagai sumber belajar. Salah satu kelemahan guru dewasa ini dalam pengelolaaan pembelajaran adalah kurangnya pemanfaatan sarana dan prasarana yang tersedia. Dibandingkan dengan profesi lain, guru termasuk profesi yang agak lamban dalam memanfaatkan berbagai sarana dan prasarana khususnya dalam memanfaatkan berbagai produk teknologi. ${ }^{40}$

Berdasarkan Peraturan Pemerintah Nomor 19 tahun 2005, ada delapan standar proses pendidikan nasional. BAB I KETENTUAN UMUM, Pasal 1 ayat 6, menyatakan bahwa standar proses yang ketiga yaitu Standar Proses Pendidikan adalah standar nasional pendidikan yang berkaitan dengan pelaksanaan pembelajaran pada satu satuan pendidikan untuk mencapai standar kompetensi lulusan. ${ }^{41}$

Lahirnya penetapan standar-standar tersebut karena dimotivasi untuk memperbaiki dan meningkatkan kualitas pendidikan yang selama ini jauh tertinggal dari negara-negara lain, ${ }^{42}$ terutama di kawasan Asia Tenggara, seperti negara-negara tetangga Malaysia, Singapura dan Thailand. Dalam upaya peningkatan mutu pendidikan, Standar Proses Pendidikan memiliki peran yang sangat urgen. Justru

\section{${ }^{39} \mathrm{Ibid} ., \mathrm{hlm} .31$.}

${ }^{40}$ Ibid., hlm. 32.

${ }^{41}$ Selain standar proses pendidikan, ada tujuh standar lain yang ditetapkan dalam standar nasional itu yaitu standar kompetensi lulusan (standar pertama, ayat 4), standar isi (standar kedua, ayat 5), standar pendidik dan tenaga kependidikan (standar keempat, ayat 7), standar sarana dan prasarana (standar kelima, ayat 8), standar pengelolaan (standar keenam, ayat 9), standar pembiayaan (standar ketujuh, ayat 10), dan standar penilaian pendidikan (standar kedelapan ayat 11). Direktorat Jenderal Pendidikan Islam, Undang-Undang dan Peraturan Pemerintah RI tentang Pendidikan, (Jakarta: Departemen Agama RI, 2006), hlm. 151.

${ }^{42 W}$ Wina Sanjaya, op.cit., hlm. xiv. itu, bagaimanapun idealnya standar isi, standar lulusan, standar pendidik, standar sarana dan prasarana, standar pengelolaan, standar pembiayaan dan standar penilaian pendidikan, tanpa didukung oleh standar proses pembelajaran yang memadai, maka standar-standar tersebut belum memiliki nilai yang bermakna. Dalam konteks demikian, standar proses pendidikan (pembelajaran) merupakan hal yang harus mendapat perhatian serius dari berbagai pihak, terutama guru, kepala sekolah, pemerintah dan orang tua murid. Dalam implementasi Standar Proses Pendidikan, guru merupakan komponen yang sangat penting, karena keberhasilan pelaksanaan proses pendidikan sangat tergantung pada guru sebagai ujung tombak dalam pembelajaran. Dengan demikian, upaya peningkatan kualitas pendidikan seharusnya dimulai dari pembenahan kemampuan guru.

Pengetahuan PAIKEM merupakan profesi yang harus dikembangkan dan diimplementasikan oleh guru sebagai tenaga pendidik dan sangat dibutuhkan oleh guru untuk menunjang keberhasilan program pendidikan di sekolah dalam semua jenjang pendidikan (PAUD, STK, SD, SMP, SMA, bahkan PT), terutama di tingkat Sekolah Menengah Pertama (Swasta) sebagai fokus kajian ini. Proses pembelajaran tidak selamanya berjalan dengan lancar bagi para siswa. Ada banyak faktor yang dapat menghambat kelancaran proses belajar mengajar itu. Di antaranya berupa :

Faktor psikologis yaitu hambatan yang bersumber dari dalam diri pribadi murid. Akibat pengaruh dari dalam diri pribadinya sendiri, misalnya, kelemahan daya penalaran (cipta), kemauan (karsa) dan emosi (rasa) atau pengaruh sosial ekonomi, misalnya masyarakat dan keluarga yang kurang memberikan dorongan ke arah belajar anak, kekurangan pembiayaan memenuhi kebutuhan sarana belajar, dan sebagainya. ${ }^{43}$

${ }^{43}$ Muzayyin Arifin, Kapita Selekta Pendidikan Islam, Jakarta: Bumi Aksara, Cetakan V, Maret 2011), hlm. 169. 
Dengan demikian, implementasi pembelajaran berbasis aktif, inovatif, kreatif, efektif dan menyenangkan dalam dunia pendidikan sangatlah penting untuk membantu mengatasi permasalahan (problem solving) tertutama bagi siswa SMP, karena mereka berada dalam perkembangan usia transisi awal masa muda (remaja) akan menghadapi masa dewasa yang penuh dengan tantangan, harapan, tanggung jawab dan hidup harus mandiri.

Suatu hal yang paling penting bagi guru-guru kita adalah bagaimana melakukan pendekatan terhadap pemecahan problemaproblema, misalnya kenakalan remaja sampai keterlibatan dalam narkotika atau dekadensi moral dalam berbagai bentuk. Pendekatanpendekatan itu sudah barang tentu didasarkan atas pengertian dan pengenalan tentang hal ihwal remaja (dan penanaman nilai-nilai agama). ${ }^{44}$

Dalam konteks penyelenggaraan pendidikan formal pembelajaran Pnedidikan Agama Islam di sekolah/madrasah terdapat sejumlah komponen urgen sebagai faktor tertentu yang mempengaruhi keberhasilan pembelajaran yaitu siswa sebagai raw input (masukan mentah), tersedianya text books (buku daras), sarana dan prasarana pendidikan sebagai instrumental input (masukan alat) yang memenuhi standar dan physical environment (lingkungan fisik) maupun lingkungan sosial budaya madrasah/sekolah yang kondusif. Di sinilah urgensinya implementasi strategi pembelajaran PAIKEM merupakan salah satu strategi yang dapat diimplementasikan dalam aktitivas pembelajaran, karena bidang garapannya terarah pada cara mengorganisasi materi pembelajaran, menyampaikan dan menggunakan metode pembelajaran dan mengelola pembelajaran untuk mengoptimalkan proses pembelajaran. To say is easy, to do is difficult, to understand is more difficult, and to make one understanding is the most difficult.

${ }^{44}$ Ibid., hlm. 170.
Demikian juga dengan mengimplementasikakan PAIKEM. Mengucapkan dan mengatakan PAIKEM memang terasa mudah. Mengerti dan memahami tentang PAIKEM diakui akan lebih sulit. Apalagi mengimplementasikan PAIKEM. Hal itu akan lebih sulit lagi. Bahkan membuat para guru dapat memahami dengan baik dan kemudian mengimplementasikannya dalam pembelajaran adalah sesuatu cukup sulit.

Strategi PAIKEM senantiasa memposisikan guru sebagai agen yang mampu menciptakan suasana belajar yang kondusif dan sebagai dinamisator dan fasilitator dalam pembelajaran. Sementara siswa sebagai peserta belajar yang harus aktif, inovatif, dimanfaatkan sebagai sumber belajar, kreatif, efektif dan menarik. Dalam proses pembelajaran PAIKEM terjadi dialog yang interaktif antara siswa dengan siswa, siswa dengan guru atau siswa dengan sumber belajar lainnya. Dalam suasana pembelajaran yang kondusif itu siswa tidak terbebani secara individu dalam problem solving yang dihadapi dalam belajar, tetapi mereka dapat saling berdiskusi, berdialog dan berdebat, sehingga belajar bagi mereka tidak menjadi beban, tetapi menjadi kebutuhan dan menyenangkan.

Lahirnya PAIKEM tidak terlepas dari realitas di mana mayoritas guru di negeri ini masih menggunakan pendekatan tradisional, strategi pembelajaran ekspositori (direct instruction) yaitu materi pelajaran disampaikan langsung oleh guru dan siswa tidak dituntut untuk menemukan materi itu), ${ }^{45}$ dalam aktivitas pembelajarannya. Guru selalu bertindak sebagai subjek, satu-satunya pusat informasi dan pengetahuan, sedangakn siswa sebagai objek yang harus diisi dengan pengetahuan yang banyak dan cukup melelahkan. Dalam sistem pembelajaran demikian, tidak ada interaksi dalam bentuk dialog, diskusi, debat pendapat, pengayaan materi dan silang pendapat. Dalam perkembangannya, pendekatan pembelajaran tradisional demikian dirasakan tidak mampu menggali potensi besar anak didik, kreativitas

${ }^{45}$ Wina Sanjaya, op.cit., hlm. 177. 
anak tidak berkembang, efektivitas pembelajaran tidak tercapai dan siswa merasa bosan dan jenuh, letih dan lelah.

Faktor peserta didik dianggap sesuatu yang menentukan dalam pelaksanaan dan keberhasilan proses pembelajaran. Pandangan baru berpendapat bahwa tingkah laku manusia dimotivasi oleh motif-motif tertentu. Aktivitas belajar akan berhasil apabila berdasarkan motivasi pada diri peserta didik. Berarti tugas guru cukup berat yaitu berupaya agar peserta didik mau belajar dan memiliki keinginan belajar secara kontinuitas tanpa dibatasi waktu (long life eduction).

PAIKEM bukanlah tujuan akhir dari aktivitas pembelajaran, tetapi merupakan salah satu strategi yang digunakan untuk mengoptimalkan proses pembelajaran. Strategi PAIKEM memposisikan guru sebagai pendidik menciptakan suasana belajar yang kondusif dan sebagai fasilitator dalam proses pembelajaran, sementara siswa sebagai peserta didik yang harus aktif, inovatif, lingkungan dimanfaatkan sebagai sumber belajar, kreatif dan menarik. Dalam proses pembelajaran PAIKEM itu terjadi dialog yang interaktif antara siswa dengan siswa, siswa dengan guru dan siswa dengan sumber belajar lainnya. Dalam suasana pembelajaran demikian itu siswa tidak terbebani secara individual memecahkan masalah yang dihadapi dalam proses pembelajaran, tapi mereka dapat saling berdiskusi, sehingga belajar bagi mereka bukan suatu beban namun menjadi kebutuhan. Dengan strategi PAIKEM ini diharapkan akan tumbuh dan berkembang segala potensi yang dimiliki oleh para siswa dan pada akhirnya dapat mengoptimalkan hasil belajar mereka yang diharapkan oleh para pendidik.

\section{Kesimpulan}

Pembelajaran Aktif, Inovatif, Kreatif, Efektif dan Menyenangkan dapat berperan dalam pelaksanaan pembelajaran PAI di sekolah/madrasah, jika implementasi PAIKEM didukung oleh Peran Serta Masyarakat (PSM) dan kesungguhan para guru serta keseriusan siswa yang ditunjang oleh berbagai fasilitas pembelajaran yang memadai. PAIKEM juga baru dapat dilaksanakan dengan baik dan benar, jika Managemen Berbasis Sekolah (MBS) telah benar-benar dilaksanakan dan mendapatkan dukungan dari orang tua dan masyarakat. Guru dapat memperkaya strategi, metode, teknik dan gaya mengajar sebagai estetis, sehingga secara psikologis pedagogis dan yuridis formal, PAIKEM memiliki relevansi dalam rangka mewujudkan proses belajar Pembelajaran Agama Islam yang mampu memberdayakan peserta didik secara maksimal. Guru dapat melakukan pengembangan, modifikasi, improvisasi dan mencari strategi dan metode yang dipandang lebih tepat dalam pembelajaran PAI. Karena pada dasarnya tidak ada strategi yang paling ideal. Masing-masing strategi memiliki kelebihan dan kekurangan sendiri. Hal ini sangat tergantung pada beberapa faktor, seperti tujuan yang hendak dicapai, pengguna strategi (guru), ketersediaan fasilitas dan kondisi peserta didik untuk mengaplikasikan PAIKEM di sekolah/madrasah. PAIKEM terkait dengan aplikasi konsep yang dikenal dengan School Based Curriculum atau Kurikulum Berbasis Kompetensi yang dalam pelaksanaannya diberi label Kurikulum Tingkat Satuan Pendidikan. Pendekatan PAIKEM dalam Pembelajaran Agama Islam merupakan integrasi dari beberapa pendekatan pembelajaran siswa aktif (Active Learning), pembelajaran berbasis masalah (Problem Based Learning), pembelajaran kooperatif (cooverative learning), pembelajaran kontekstual (Contextual Teaching and Learning), yang didukung oleh berbagai konsep dan teori pembelajaran, terutama constructivism theory (teori konstruktivisme).

\section{Bibliografi}

Ahmadi, Iif Khoiri, dan Amri, Sofyan, April 2012, PAIKEM GEMBROT: Mengembangkean Pembelajran Aktif, Inovatif, Kreatif, Efektif, Menyenangkan, Gembira dan Berbobot, Jakarta: Prestasi Pustakakarya, Cetakan II. 
Al-Nahlawi, Abdurrahman, , Agustus 2004, Ushâl al-Tarbiyyah alIslâmiyyah wa Asâlîbihâ, penerjemah Shihabuddin, Pendidikan Islam: Di Rumah, Sekolah dan Masyarakat, Jakarta: Gema Insani, Cetakan IV.

Arifin, Muzayyin, Maret 2011, Kapita Selekta Pendidikan Islam, Jakarta: Bumi Aksara, Cetakan V.

Budimansyah, Dasim, Suparlan dan Meirawan, Danny, Desember 2010, PAKEM : Pembelajaran Aktif, Kreatif, Efektif dan Menyenangkan, Bandung : Genesindo, Cetakan V.

Direktorat Jenderal Pendidikan Islam, 2007, Kumpulan Undang-Undang dan Peraturan Pemerintah tentang Pendidikan, Jakarta : Dirjen Pendis Depag RI.

Dimyati dan Mudjiono, Februari 2006, Belajar dan Pembelajaran, Jakarta : Rineka Cipta, Cetakan II.

Hartono, Promadi, dkk, Januari 2011, PAIKEM : Pembelajaran Aktif, Inovatif, Kreatif, Efektif dan Menyenangkan, Pekanbaru : Zanafa Publishing, Cetakan III.

Ismail, 2009, Strategi Pembelajaran Agama Islam Berbasis PAIKEM, Semarang : Media Group, Cetakan IV.

Jauhar, Mohammad, Nopember 2011, Implementasi PAIKEM dari Behavioristik sampai Konstruktivistik, Jakarta: Prestasi Pustakakarya, Cetakan I.

Langgulung, Hasan, Oktober 2003, Pendidikan Islam dalam Abad ke 21, Jakarta : Pustaka al-Husna Baru, Cetakan III.

---, April 2002, Peralihan Paradigma dalam Pendidikan Islam dan Sains Sosial, Jakarta: Gaya Media Pratama, Cetakan I.

M.Echols, John dan Shadily, Hassan, Februari 2003, An EnglishIndonesian Dictionary, Jakarta : Gramedia Pustaka Utama, Cetakan XXV.
Muhmidayeli, Maret 2011, Filsafat Pendidikan, Bandung: Refika Aditama, Cetakan Kesatu.

-, Oktober 2007, Teori-Teori Pengembangan Sumber Daya Manusia, Pekanbaru: PPs UIN suSka Riau dan LSFK2P, Cetakan Kesatu.

--, et.al, Juni 2007, Membangun Paradigma Pendidikan Islam, Pekanbaru: PPs UIN Suska Riau, Cetakan I.

Mulyana, E, 2003, Kurikulum Berbasis Kompetensi, Konsep, Karakteristik dan Implementasi, Bandung : Remaja Rosdakarya.

Nata, Abudin, Oktober 2009, Perspektif Islam tentang Strategi Pembelajaran, Jakarta : Kencana, Cetakan I.

Peraturan Pemerintah Nomor 10/2010 tentang Pengelolaan dan Penyelenggaraan Pendidikan, Yogyakarta : Pustaka Timur, 2010.

Sanjaya, Wina, Maret 2009, Strategi Pembelajaran Berorientasi Standar Proses Pendidikan, Jakarta : Kencana, Cetakan VI. --, 2003, Perencanaan dan Desain Sistem Pembelajaran, Jakarta : Kencana, Cetakan III.

Tim Prima Pena, t.th., Kamus Besar Babasa Indonesia, edisi terbaru, Jakarta : Gitamedia, Press.

Wehr, Hans, 1974, A Dictionary of Modern Written Arabic, Arabic-English, edited by J.Milton Cowan, Beirut : Maktabah Lubnan, Cetaka IV. 